Klinička psihologija 9 (2016), 2, 257-270

Izvorni znanstveni članak - UDK 159.923.5

DOI: 10.21465/2016-KP-2-0004

\title{
POVEZANOST KVALITETE ŽIVOTA I NAČINA SUOČAVANJA SA STRESOM KOD MEDICINSKIH SESTARA
}

\author{
Mirna Arapović \\ Osnovna škola Ive Andrića \\ Milovana Kovačevića, 10010, Zagreb \\ mirnarapovic@gmail.com \\ Jasminka Despot Lučanin \\ Odsjek za psihologiju, Hrvatski studiji Sveučilišta u Zagrebu \\ Borongajska 83d, 10000 Zagreb \\ jdespot@hrstud.hr
}

\begin{abstract}
Sažetak
Ciljevi ovog istraživanja bili su ispitati kvalitetu života, stresnost posla i načine suočavanja sa stresom kod medicinskih sestara zaposlenih u bolnici te utvrditi doprinose li neke sociodemografske karakteristike, samoprocjena stresnosti posla i strategije suočavanja sa stresom predviđanju kvalitete u različitim domenama života medicinskih sestara. Ispitane su 133 medicinske sestre ( $88 \%$ žena) u dobi od 20 do 63 godine, zaposlene u Kliničkom bolničkom centru Zagreb. Primijenjeni su upitnici: općih podataka i samoprocjene stresnosti posla, skraćena verzija COPE upitnika suočavanja sa stresnim situacijama te skraćena verzija upitnika kvalitete života WHOQOL-BREF, koji obuhvaća četiri domene: tjelesno zdravlje, psihičko stanje, društvenu interakciju i okoliš. Rezultati su pokazali da je kvaliteta života medicinskih sestara dobra u svim domenama, a razina stresnosti posla je jako visoka. Ispitane medicinske sestre najčešće koriste strategije suočavanja usmjerene na problem, a najrjeđe izbjegavajuće strategije. Niža razina samoprocjene stresnosti posla i viši stupanj obrazovanja značajni su prediktori bolje kvalitete života u domenama tjelesnog zdravlja i psihičkog stanja. Viša razina stresnosti posla jedini je značajni prediktor lošije kvalitete života u domeni okoliša. Učestalije izbjegavajuće suočavanje jedini je značajni prediktor lošije kvalitete života u domeni društvenih odnosa. Rezultati istraživanja mogu biti korisni u planiranju intervencija i edukacija za poboljšanje suočavanja sa stresom medicinskih sestara.
\end{abstract}

Ključne riječi: kvaliteta života, medicinske sestre, stres na radnom mjestu, suočavanje sa stresom 


\section{UVOD}

Kvaliteta života medicinskih sestara zanimljivo je i relevantno područje koje vrijedi opsežnije istražiti zbog njihove velike uloge u bolničkom liječenju, koja se prvenstveno ostvaruje kroz neposredan kontakt s bolesnicima, pri čemu se može pretpostaviti da percepcija kvalitete života medicinskih sestara izravno ili neizravno djeluje na kvalitetu njihova rada i odnos prema bolesnicima (Cimete, Gencalp i Keskin, 2003).

U definiciji Svjetske zdravstvene organizacije kvaliteta života opisana je kao percepcija vlastitog položaja u životu u kontekstu kulture i sustava vrijednosti u kojem pojedinac živi te u odnosu s njegovim vlastitim ciljevima, očekivanjima, standardima i interesima (WHO, 1996). S obzirom na složenost i širinu samog koncepta, kvalitetu života treba promatrati u kontekstu drugih varijabli i konstrukata s kojima je povezana. U proučavanju kvalitete života medicinskih sestara, a zbog odgovornosti njihove struke prema zdravstvenoj dobrobiti ljudi, relevantnim varijablama i konstruktima pokazale su se neke sociodemografske značajke - dob, obrazovanje i radni staž, zatim stres na radnom mjestu - za koji se pokazalo nepovoljno djelovanje na različite aspekte kvalitete života medicinskih sestara zaposlenih na različitim bolničkim odjelima (Aytekin, Kuguoglu i Yilmaz, 2014; Hamaideh, 2012; Wu, Li, Wang, Yang i Qiu, 2011) te strategije suočavanja sa stresom - zbog mogućnosti ublažavanja štetnih posljedica stresa i poboljšanja kvalitete života. Ipak, povezanost između ovih konstrukata trebalo bi dodatno istražiti.

U većini dosadašnjih istraživanja utvrđena je povezanost kvalitete života zdravstvenih djelatnika s nekim sociodemografskim varijablama kao što su: dob - koju se negativno povezuje s kvalitetom života (Pastuović, Kolesarić i Krizmanić, 1995; Sorić, Golubić, Milošević, Juras i Mustajbegović, 2013), stupanj obrazovanja koji se pokazao pozitivno povezan s kvalitetom života zbog pretpostavljenih boljih strategija suočavanja sa stresnim situacijama (Cimete i sur, 2003; Pastuović i sur., 1995; Sorić i sur., 2013); radni staž - čija je duljina, odnosno veće radno iskustvo, povezana s boljom kvalitetom života (Arafa, Nazel, Ibrahim i Attia, 2003; Cimete i sur., 2003).

Proučavanje kvalitete života zdravstvenih djelatnika slabije je obuhvaćeno istraživanjima u odnosu na proučavanje stresa i izgaranja na radnom mjestu (Vuletić i Misajon, 2011). Stres na radnom mjestu je pojava koja se sve češće povezuje s kvalitetom života zaposlenika iz različitih profesija. Više autora u Hrvatskoj utvrdilo je da su najučestaliji i najjači stresori za medicinsko osoblje financijski i organizacijski čimbenici, primjerice: nepredviđena dežurstva, nedostatak osoblja, nedostatak vremena za izvršavanje zadataka, rad za vrijeme stanke, previše administracije te prekovremeni i smjenski rad (Dušak, 2012; Knežević, Golubić, Milošević, Matec i Mustajbegović, 2009; Marlais i Hudorović, 2015; Milutović, Grujić i Jocić, 2009). Utvrđene su štetne posljedice stresa na radu na tjelesno zdravlje i dobrobit medicinskih sestara. To su: glavobolje (Lin, Huang i Wu, 2007), križobolja (Eriksen, 
Bruusgaard i Knardahl, 2004), povišen krvni tlak (Mačvanin i Prokeš, 2005) te fizička (Winwood, Winefeld i Lushington, 2006) i emocionalna iscrpljenost (Hunter, 2004). U istraživanjima se pokazala negativna povezanost između stresa na radnom mjestu i različitih domena kvalitete života zdravstvenih djelatnika, a osobito stresora vezanih uz uvjete okoline i uvjete rada (Aytekin i sur., 2014; Hamaideh, 2012; Wu i sur., 2011). Stres na radnom mjestu može nepovoljno djelovati na radnu učinkovitost zdravstvenih djelatnika, što izravno narušava kvalitetu skrbi i sigurnost bolesnika (Sveinsdottir, Biering i Ramel, 2006; Vahey, Aiken, Sloane, Clarke i Vargas, 2004; Wakefield, Blegen,Uden-Holman, Vaughn, Chrischilles i Wakefield, 2001).

Jedna od najpoznatijih teorija stresa (Lazarus i Folkman, 2004) opisuje stres kroz dva procesa: kognitivnu procjenu kojom se neki događaj određuje kao prijeteći za pojedinca te suočavanje koje je odgovor pojedinca na percipiranu prijetnju. Jedna je funkcija suočavanja kontrola ili mijenjanje problema, što se vjerojatnije odabire ako osoba procijeni da se prijeteći uvjeti okoline mogu mijenjati, a u suprotnome se vjerojatnije odabire druga funkcija suočavanja - upravljanje emocionalnim reakcijama. Treći oblik odgovora pojedinca na prijetnju je izbjegavajuće suočavanje koje sprječava da anksioznost prevlada u situacijama koje ne može kontrolirati (Carver, Scheier i Waintraub, 1989; Hudek-Knežević, Kardum i Vukomirović, 1999; Krapić i Kardum, 2003). Strategije suočavanja su promjenjivi načini ponašanja koje je moguće usvojiti, a ne stabilne osobine ličnosti. U većini istraživanja utvrđeno je da medicinske sestre češće koriste učinkovitije strategije, usmjerene na problemsko i emocionalno suočavanje, a rjeđe koriste izbjegavajuće strategije (Ashker, Penprase i Salman, 2012; Cai, Li i Zhong, 2008; Lee, 2003; Ribeiro, Popmeo, Pinto i Ribeiro, 2014; Wong, Leung i So, 2001).

Primjena korisnih strategija suočavanja može bitno ublažiti štetne utjecaje stresnih situacija, čime se poboljšava kvaliteta života. Nismo našli istraživanja u Hrvatskoj koja izravno povezuju kvalitetu života i načine suočavanja sa stresom kod medicinskih sestara. Ciljevi ovog istraživanja bili su, kao prvo, ispitati kvalitetu života, stresnost posla i načine suočavanja sa stresom kod medicinskih sestara zaposlenih u bolnici, a kao drugo, utvrditi doprinose li neke sociodemografske karakteristike, samoprocjena stresnosti posla i strategije suočavanja sa stresom predviđanju kvalitete $\mathrm{u}$ različitim domenama života medicinskih sestara.

\section{METODA}

\section{Sudionici}

Sudionici istraživanja bile su 133 pripadnice (pripadnici) sestrinske profesije zaposlene u bolnici na različitim odjelima Kliničkog bolničkog centra Zagreb, 117 (88\%) ženskog i 16 (12\%) muškog spola. Dobni raspon bio je od 20 do 63 godine, 
a prosječna dob 40 godina $(M=40,15 ; S D=12,46)$. Najviše sudionika bilo je srednje stručne spreme (57\%), zatim više (36\%) i visoke stručne spreme (7\%). Raspon ukupnog radnog staža bio je od 0 do 43 godine, s prosječnom vrijednošću od 20 godina $(M=19,92 ; S D=12,95)$.

\section{Instrumenti}

Upitnik općih podataka sastavljen za potrebe ovog istraživanja, a obuhvaća podatke o spolu, dobi, obrazovanju (od 1= srednje obrazovanje, do $3=$ visoko obrazovanje) te duljini radnog staža sudionika (izraženo u godinama). Na kraju ovog upitnika sudionici su procjenjivali stresnost njihova trenutačnog posla na ljestvici od 1 do 5, pri čemu je 1 označavalo najnižu razinu stresa, a 5 najvišu.

Upitnik kvalitete života Svjetske zdravstvene organizacije WHOQOL-BREF, skraćena verzija (WHO, 1996), preveden na hrvatski jezik (Golubić, 2010; PibernikOkanović, 2001) obuhvaća četiri domene: tjelesno zdravlje (npr.: "Imate li dovoljno energije za svakidašnji život?”), psihičko stanje (npr.: “Koliko uživate u životu?”), društvenu interakciju (npr.: "Koliko ste zadovoljni podrškom što Vam je daju Vaši prijatelji?") i okoliš (npr.: “Imate li prilike za rekreaciju?") te po jednu česticu za procjenu kvalitete života u cjelini i za procjenu općeg zdravlja. Upitnik sadrži 26 pitanja, a odgovori na svako se boduju ljestvicom od 1 (najlošije) do 5 (najbolje). Bodovi za svaku domenu transformiraju se na skalu od 0 do 100, prema priručniku upitnika. Veći broj bodova predstavlja bolju kvalitetu života. Ispitanici s rezultatom većim od 60 imaju dobru kvalitetu života u pojedinoj domeni. Cronbachov $\alpha$ koeficijent unutarnje pouzdanosti za pojedine domene u drugim istraživanjima bio je od 0,66 do 0,84 (Skevington, Lotfy i O'Connell, 2004; World Health Organization, (1998), a u ovom istraživanju iznosio je od 0,52 do 0,80 . Upitnik je korišten uz odobrenje autorice hrvatske verzije.

Upitnik suočavanja sa stresnim situacijama The Cope Inventory, skraćena verzija (Carver, 1997), preveden je, adaptiran i validiran na hrvatskom jeziku (Hudek-Knežević i Kardum, 1993). Upitnik se sastoji od 17 tvrdnji koje obuhvaćaju procjene uobičajenih načina reagiranja ljudi u stresnim situacijama, u rasponu od 0 (nikada se tako ne ponašam) do 4 (gotovo uvijek se tako ponašam). U hrvatskoj adaptaciji upitnika, izbjegavajuće suočavanje uključuje dvije dodatne čestice: suzdržavanje osjećaja i povlačenje u sebe, kojih nema u izvornom upitniku Carvera, Scheiera i Weintrauba (1989). Tvrdnje upućuju na tri empirijski definirana faktora na temelju kojih se formiraju tri ukupna rezultata: problemsko suočavanje u rasponu od 0 do 28 , emocionalno suočavanje u rasponu od 0 do 12 i izbjegavajuće suočavanje s izbjegavanjem u rasponu od 0 do 28 . Veći broj bodova predstavlja veću učestalost pojedinog načina suočavanja. Cronbachov $\alpha$ koeficijent unutarnje pouzdanosti za pojedine faktore $u$ drugim hrvatskim istraživanjima bio je veći od 0,70 (Hudek- Knežević i Kardum, 1993), a u ovom istraživanju iznosio je od 0,51 do 0,56 . Upitnik je korišten uz odobrenje autora hrvatske verzije. 


\section{Postupak}

Istraživanje je grupno vođeno, na predavanju stručnog usavršavanja medicinskih sestara Kliničkog bolničkog centra Zagreb. U uputi je ukratko objašnjen cilj istraživanja, napomenuto da je sudjelovanje anonimno i dobrovoljno, a sudionici su zamoljeni da samostalno popune upitnike. Popunjavanje upitnika trajalo je desetak minuta, sljedećim redoslijedom: upitnik općih podataka, samoprocjena stresnosti posla, upitnik kvalitete života te upitnik strategija suočavanja sa stresom.

\section{REZULTATI}

\section{Deskriptivni podaci}

Ispitane medicinske sestre procijenile su kvalitetu svog života u cjelini prilično dobrom $(M=3,67 ; S D=0,75)$, na ljestvici procjene od 1 do 5 . Na istoj ljestvici procjene prilično dobrim procjenjuju i svoje opće zdravlje $(M=3,76 ; S D=0,96)$.

U Tablici 1 prikazani su deskriptivni podaci četiri domene kvalitete života, samoprocjene stresnosti posla i tri načina suočavanja sa stresnim situacijama. Ispitane medicinske sestre procjenjuju kvalitetu života u svim domenama prilično dobrom $(M>60)$. Kvaliteta u domeni okoliša pokazala se ipak značajno manje dobrom od kvalitete $\mathrm{u}$ ostale tri domene koje se odnose na tjelesno zdravlje (t-test $=4,82$; $\mathrm{p}<0,001)$, psihičko stanje (t-test $=6,29 ; \mathrm{p}<0,001)$ i društvenu interakciju (t-test $=$ $4,01 ; \mathrm{p}<0,001)$. Ispitane medicinske sestre svoj posao procjenjuju izrazito stresnim $(\mathrm{M}=4,15)$. Sudionice u prosjeku često koriste strategiju suočavanja sa stresom usmjerenu na problem, a strategiju suočavanja usmjerenu na emocije koriste pone-

Tablica 1. Deskriptivni podaci domena kvalitete života, samoprocjene stresnosti posla i načina suočavanja sa stresom $(N=133)$

\begin{tabular}{lrrrrc}
\hline Varijable & \multicolumn{1}{c}{$M$} & \multicolumn{1}{c}{$S D$} & Min & Max & $\begin{array}{c}\text { Teorijski } \\
\text { raspon }\end{array}$ \\
\hline Tjelesno zdravlje & 69,14 & 16,43 & 25 & 94 & $0-100$ \\
Psihičko stanje & 70,43 & 15,30 & 31 & 100 & $0-100$ \\
Društvena interakcija & 69,65 & 19,42 & 0 & 100 & $0-100$ \\
Okoliš & 63,83 & 16,08 & 19 & 100 & $0-100$ \\
Stresnost posla & 4,15 & 0,96 & 1 & 5 & $1-5$ \\
Problemsko suočavanje & 19,98 & 3,44 & 10 & 28 & $0-28$ \\
Emocionalno suočavanje & 7,29 & 2,25 & 2 & 12 & $0-12$ \\
Izbjegavajuće suočavanje & 12,19 & 3,42 & 3 & 22 & $0-28$ \\
\hline
\end{tabular}


kad. Strategiju izbjegavajućeg suočavanja sa stresom sudionice u prosjeku koriste rijetko.

\section{Analiza povezanosti među varijablama}

U Tablici 2 prikazane su korelacije između varijabli u istraživanju. Zbog visoke korelacije s dobi, varijabla staž isključena je iz daljnjih analiza.

Sljedeće korelacije su statistički značajne: dob je negativno povezana s domenom društvene interakcije, dok je stupanj obrazovanja pozitivno povezan sa samoprocjenom stresnosti posla i domenom psihičkog stanja; stresnost posla negativno korelira s tri domene kvalitete života - tjelesnim zdravljem, psihičkim stanjem i okolišem; sve domene kvalitete života međusobno su srednje pozitivno povezane, što je očekivano s obzirom na teorijsku bliskost; izbjegavajuće strategije suočavanja negativno su povezane s domenom društvene interakcije.

Provedene su linearne regresijske analize s ciljem utvrđivanja mogućnosti predviđanja domena kvalitete života na temelju dobi, stupnja obrazovanja, samoprocjene stresnosti posla i tri strategije suočavanja sa stresom. U svim analizama uključene prediktorske varijable su iste, dok su kriterijske varijable redom: tjelesno zdravlje, psihičko stanje, društvena interakcija i okoliš.

Tablica 2. Koeficijenti korelacije (Pearsonov $r)$ između mjerenih varijabli $(N=133)$

\begin{tabular}{|c|c|c|c|c|c|c|c|c|c|c|}
\hline Varijable & 1 & 2 & 3 & 4 & 5 & 6 & 7 & 8 & 9 & 10 \\
\hline 1 Dob & 1 & & & & & & & & & \\
\hline 2 Obrazovanje & 0,06 & 1 & & & & & & & & \\
\hline 3 Staž & $0,99 * *$ & 0,02 & 1 & & & & & & & \\
\hline 4 Stresnost posla & 0,14 & $0,19 *$ & 0,13 & 1 & & & & & & \\
\hline $\begin{array}{l}5 \text { Tjelesno } \\
\text { zdravlje }\end{array}$ & 0,05 & 0,14 & 0,01 & $-0,28 * *$ & 1 & & & & & \\
\hline 6 Psihičko stanje & $-0,04$ & $0,17 *$ & $-0,07$ & $-0,17^{*}$ & $0,63 * *$ & 1 & & & & \\
\hline $\begin{array}{l}7 \text { Društvena } \\
\text { interakcija }\end{array}$ & $-0,17 *$ & $-0,02$ & $-0,19 *$ & $-0,06$ & $0,46^{* *}$ & $0,59 * *$ & 1 & & & \\
\hline 8 Okoliš & $-0,01$ & 0,02 & $-0,03$ & $-0,37 * *$ & $0,69 * *$ & $0,70 * *$ & $0,57 * *$ & 1 & & \\
\hline $\begin{array}{l}9 \text { Problemsko } \\
\text { suočavanje }\end{array}$ & 0,14 & 0,13 & 0,12 & 0,10 & 0,03 & $-0,05$ & $-0,07$ & $-0,11$ & 1 & \\
\hline $\begin{array}{l}10 \text { Emocionalno } \\
\text { suočavanje }\end{array}$ & $-0,11$ & 0,04 & $-0,13$ & 0,14 & $-0,05$ & $-0,01$ & 0,04 & $-0,04$ & $0,35^{* *}$ & 1 \\
\hline $\begin{array}{l}11 \text { Izbjegavajuće } \\
\text { suočavanje }\end{array}$ & 0,02 & $-0,13$ & 0,03 & $-0,01$ & $-0,15$ & $-0,16$ & $-0,26 * *$ & $-0,17$ & $0,18^{*}$ & 0,12 \\
\hline
\end{tabular}

$* *=p<0,01 ; *=p<0,05$ 
Tablica 3. Rezultati linearnih regresijskih analiza: predviđanje domena tjelesnog zdravlja, psihičkog stanja, društvene interakcije i okoliša kao kriterijskih varijabli $(N=133)$

\begin{tabular}{lcccc}
\hline Prediktorske varijable & $\beta_{1}$ & $\beta_{2}$ & $\beta_{3}$ & $\beta_{4}$ \\
\hline Dob & 0,073 & $-0,016$ & $-0,151$ & 0,058 \\
Obrazovanje & $0,171^{*}$ & $0,201^{*}$ & $-0,032$ & 0,081 \\
Stresnost posla & $-0,324^{* *}$ & $-0,208^{*}$ & $-0,037$ & $-0,393^{*}$ \\
Problemsko suočavanje & 0,059 & $-0,044$ & $-0,016$ & $-0,087$ \\
Emocionalno suočavanje & $-0,011$ & 0,038 & 0,066 & 0,066 \\
Izbjegavajuće suočavanje & $-0,141$ & $-0,133$ & $-0,264^{*}$ & $-0,149$ \\
\hline $\mathrm{R}^{2}$ & 0,14 & 0,10 & 0,10 & 0,18 \\
\hline $\mathrm{F}$ & $3,43^{* *}$ & $2,19 *$ & $2,34^{*}$ & $4,54^{* *}$ \\
& $(6,126)$ & $(6,126)$ & $(6,126)$ & $(6,126)$ \\
\hline
\end{tabular}

$\beta_{1}=$ Beta koeficijent za domenu tjelesno zdravlje; $\beta_{2}=$ Beta koeficijent za domenu psihičko stanje; $\beta_{3}=$ Beta koeficijent za domenu društvena interakcija; $\beta_{4}=$ Beta koeficijent za domenu okoliš.

$* *=p<0,01 ; *=p<0,05$

Na temelju skupa promatranih prediktorskih varijabli (Tablica 3) objašnjeno je 14\% ukupne varijance domene tjelesnog zdravlja i 10\% ukupne varijance domene psihičkog stanja medicinskih sestara. Statistički su značajne prediktorske varijable za obje domene stupanj obrazovanja i samoprocjena stresnosti posla. Viši stupanj obrazovanja predviđa bolju kvalitetu tjelesnog zdravlja i bolju kvalitetu psihičkog stanja, dok viša procjena stresnosti posla predviđa lošiju kvalitetu tjelesnog zdravlja i lošiju kvalitetu psihičkog stanja.

U trećoj regresijskoj analizi skupom promatranih prediktorskih varijabli (Tablica 3) objašnjeno je 10\% ukupne varijance domene društvene interakcije. Jedina statistički značajna prediktorska varijabla u ovoj analizi je izbjegavajuće suočavanje sa stresom. Češće korištenje izbjegavajuće strategije suočavanja predviđa lošiju kvalitetu života ispitanih medicinskih sestara u domeni društvene interakcije.

U četvrtoj analizi skupom promatranih prediktorskih varijabli (Tablica 3) objašnjeno je 18\% ukupne varijance domene okoliša. Jedina statistički značajna prediktorska varijabla u ovoj analizi je samoprocjena stresnosti posla. Procjena posla više stresnim predviđa lošiju kvalitetu života ispitanih medicinskih sestara u domeni okoliša.

\section{RASPRAVA}

U okviru prvog cilja ovog istraživanja utvrđena je kvaliteta života ispitanih medicinskih sestara u četiri domene koje obuhvaćaju tjelesno zdravlje, psihičko stanje, društvenu interakciju i okoliš. Rezultati pokazuju da je kvaliteta života sestrinskog 
osoblja zadovoljavajuća u sve četiri domene. Prosječni rezultat dobiven u domeni okoliša ipak je značajno niži od rezultata u ostalim domenama, među kojima nema značajnih razlika u dobivenim prosječnim rezultatima. Ovi nalazi u skladu su s rezultatima drugih istraživanja kvalitete života zdravstvenih djelatnika (Golubić i Mustajbegović, 2011; Sorić i sur. 2013) u kojima se kvaliteta života u domeni okoliša također pokazala najlošijom, dok je u ostalima domenama bila vrlo dobra. $\mathrm{S}$ obzirom na slične nalaze bilo bi korisno utvrditi proizlazi li niže zadovoljstvo u domeni okoliša upravo iz radne okoline, primjerice, zbog potencijalnih opasnosti i štetnih utjecaja na radnom mjestu, smjenskog rada ili drugih organizacijskih i financijskih čimbenika koji su se pokazali povezanima sa stresom u medicinskih sestara (Dušak, 2012; Knežević i sur., 2009; Marlais i Hudorović, 2015; Sorić i sur. 2013) ili možda i iz privatnog okoliša (način stanovanja, mogućnost rekreacije i sl.). Na temelju nalaza ovog i drugih istraživanja možemo pretpostaviti da postoji potreba za intervencijama i promjenama u organizaciji rada medicinskih sestara i radnoj okolini općenito.

Prvi je cilj istraživanja obuhvaćao i procjenu stresnosti posla te utvrđivanje načina suočavanja koje medicinske sestre u bolnici koriste u svakodnevnim stresnim situacijama. Ispitane medicinske sestre svoj su posao procijenile vrlo stresnim, što je utvrđeno i u brojnim drugim istraživanjima (Chen, Lin, Wang i Hou, 2009; Gazivoda, 2015; Hamaideh, 2012; Jones, Wells, Gao, Cassidy i Davie, 2013). Iako nalazi u ovom području nisu konzistentni, većina istraživanja pokazuje da medicinsko osoblje često koristi problemsko i emocionalno suočavanje sa stresom, dok se izbjegavajuće suočavanje koristi rijetko (Ashker i sur., 2012; Cai i sur., 2008; Lee, 2003; Ribeiro i sur., 2014; Wong, Leung i So, 2001). Slično je dobiveno i u ovom istraživanju. Od pojedinačnih ponašanja u okviru strategija suočavanja s problemom i suočavanja s emocijama najviše koriste strategije planiranja, prihvaćanja, aktivnog suočavanja i pozitivne interpretacije. U okviru izbjegavajućeg suočavanja jako rijetko uzimaju alkohol ili sredstvo za smirenje. Također, rijetko koriste strategije negiranja i fizičke izolacije, tj. povlačenja u sebe. Objašnjenje ovih rezultata možda potječe od pretpostavke da izbor strategije suočavanja koja će se koristiti velikim dijelom ovisi o prirodi situacije (Lazarus i Folkman, 2004). S obzirom na to da posao medicinskih sestara i drugih zdravstvenih djelatnika često zahtijeva brza i učinkovita rješenja, prikladnije i korisnije strategije su one koje uključuju aktivno i izravno suočavanje s problemom. Također, neka istraživanja pokazuju da ljudi izbjegavajuće suočavanje češće koriste u interpersonalnim konfliktima kako bi očuvali ravnotežu odnosa (Wong i sur., 2001), a u zdravstvu je ona preduvjet timskog rada.

Drugi cilj ovog istraživanja bio je utvrditi mogućnost predviđanja domena kvalitete života medicinskih sestara na temelju sociodemografskih varijabli dobi i stupnja obrazovanja te samoprocjene stresnosti posla i strategija suočavanja sa stresom. Rezultati pokazuju da dob nije značajan prediktor nijedne domene kvalitete života, unatoč značajnoj bivarijatnoj korelaciji s domenom društvene interakcije koja upu- 
ćuje na to da se kvaliteta u ovoj domeni s dobi smanjuje. Druga istraživanja pokazuju nejednoznačne rezultate, ali u nekima je također utvrđeno da se kvaliteta života s dobi smanjuje (Pastuović i sur., 1995; Sorić i sur., 2013).

Viši stupanj obrazovanja ispitanih medicinskih sestara pokazao se značajnim u predviđanju njihove bolje kvalitete života u domenama tjelesno zdravlje i psihičko stanje. Slični rezultati dobiveni su u prijašnjim istraživanjima (Cimete i sur., 2003; Pastuović i sur., 1995; Sorić i sur., 2013). Moguće objašnjenje ovakvog rezultata je da obrazovanije sestrinsko osoblje ima bolje kompetencije, što znači i bolju radnu sposobnost, koja se pokazuje dobrim prediktorom kvalitete života u svim domenama (Milošević, Golubić, Mustajbegović, Doko Jelinić, Janev Holcer i Kern, 2009).

Samoprocjena stresnosti posla pokazala se najboljim prediktorom tri domene kvalitete života u ovom istraživanju: tjelesnog zdravlja, psihičkog stanja i okoliša. $\mathrm{U}$ dosadašnjim istraživanjima pokazalo se da je stres na poslu negativno povezan s različitim kroničnim zdravstvenim stanjima i bolestima (Belkic i Nedic, 2007; Eriksen i sur., 2004; Lin i sur., 2007; Mačvanin i Prokeš, 2005). Doprinos ovog istraživanja je utvrđena negativna povezanost između stresnosti posla i psihičkog stanja, unatoč razmjerno dobroj kvaliteti života u domeni psihičkog stanja. Ovakvi nalazi jasno pokazuju da visoka razina stresa na radnom mjestu može djelovati na sveukupno zdravlje medicinskih sestara. To može biti povezano s kombiniranim djelovanjem različitih čimbenika kao što su nesanica, napetost, anksioznost te emocionalna i tjelesna iscrpljenost. Kvaliteta okoliša također se pokazala negativno povezanom sa samoprocjenom stresa na radu, što je ujedno jedini značajan prediktor te domene. Moguća objašnjenja su da se sestrinsko osoblje često osjeća tjelesno ugroženo uz nezdrave okolišne uvjete, što može doprinijeti pojačanom osjećaju napetosti i stresa ili da medicinske sestre strahuju od pogrešaka na poslu i potencijalnih sankcija, što pojačava razinu stresa na radnom mjestu. Kako bi se ovakav rezultat dodatno razjasnio, trebalo bi provjeriti koliko je kvaliteta okoliša mjerena u ovom istraživanju izravno vezana uz sam posao i radno mjesto, a koliko uz privatni životni okoliš.

Izbjegavajuće suočavanje sa stresom pokazalo se jedinom značajnom od tri promatrane strategije suočavanja u predviđanju kvalitete života u domeni društvene interakcije. Drugim riječima, osobe koje češće koriste izbjegavajuće strategije, vjerojatnije će imati lošiju kvalitetu društvenih odnosa, što je djelomično utvrđeno i u drugim istraživanjima (Lee, 2003; Loukzadeh i Mazloom, 2013; Qiao, Li i Hu, 2011; Wong i sur., 2001; Yu i sur., 2012). Vrijedilo bi ispitati socijalnu podršku okoline i odnose među kolegama na radnom mjestu jer rezultati drugih istraživanja pokazuju da su dobri međuljudski odnosi u zdravstvenom timu važni čimbenici u smanjenju razine stresa (Matulović, Rončević i Sindik, 2012).

Uz prikazane rezultate regresijskih analiza treba dodatno naglasiti da je postotak objašnjene ukupne varijance u svim domenama kvalitete života razmjerno nizak, od 10 do $18 \%$. To je djelomično očekivano ako uzmemo u obzir da je kvaliteta života širok konstrukt koji obuhvaća različite aspekte života pojedinca. Bilo bi korisno u budućim istraživanjima ispitati eventualne medijatorske povezanosti još nekih dru- 
gih čimbenika kvalitete življenja kao što su npr. osobine ličnosti, socijalna podrška, anksioznost i drugo.

Provedeno istraživanje ima određene nedostatke i ograničenja koja su mogla djelovati na dobivene rezultate. Prvenstveno, radi se o korelacijskom istraživanju, zbog čega nije moguće donijeti zaključke o uzročno-posljedičnim vezama među promatranim varijablama. Također, sve primijenjene mjere temelje se na samoprocjeni sudionika pa zaključke treba donositi s oprezom. Nadalje, uzorak je prigodan, razmjerno malen i ograničen na medicinske sestre samo jedne bolnice, što onemogućuje generalizaciju rezultata na širu sestrinsku populaciju. Istraživanje je provedeno na predavanju stručnog osposobljavanja medicinskih sestara pa je moguće da je kod nekih sudionika bio prisutan umor ili nezainteresiranost, što se moglo odraziti na pouzdanost mjernih instrumenata. $U$ budućim istraživanjima bilo bi korisno ispitati razlike među bolničkim odjelima i proširiti uzorak na druge bolnice i zdravstvene ustanove. Također, bilo bi dobro obuhvatiti i druge varijable koje bi mogle imati ulogu u odnosu kvalitete života i načina suočavanja sa stresom.

Glavni je znanstveni doprinos ovog istraživanja utvrđena povezanost između strategija suočavanja sa stresom i kvalitete života medicinskih sestara te važnost samoprocjene stresnosti posla za predviđanje većine domena kvalitete života medicinskih sestara, u odnosu na ostale varijable uključene u istraživanje. Unatoč tome što se pokazalo da je kvaliteta života medicinskih sestara u svim domenama dobra, iz visoke procijenjene stresnosti posla te iz odabira strategija suočavanja sa stresom jasno proizlazi važnost intervencija i edukacija o različitim tehnikama i strategijama koje pomažu u suočavanju i ublažavanju štetnih posljedica stresa. Naime, u sestrinskoj struci posljedice stresa često, osim što djeluju na medicinsko osoblje, djeluju na bolesnika i njegovu obitelj odnosno umanjuju kvalitetu sestrinske skrbi za bolesnika. Mali je broj istraživanja stranih autora koji su proučavali intervencije za suočavanje sa stresom zdravstvenih djelatnika, dok ih u Hrvatskoj praktički nema. Učinkovitim se pokazao trening prepoznavanja stresnih simptoma, načina suočavanja, tehnika relaksacije, učinkovite komunikacije te strategija rješavanja problema (Onan, Isil i Barlas, 2013). Osim toga, a u svrhu poboljšanja organizacije rada, poslodavci mogu organizirati: supervizije, grupe podrške te fokus grupe u cilju dobivanja uvida o problemima u nekom radnom okruženju, a i izvan njega.

\section{ZAKLJUČAK}

Prikazano istraživanje bavilo se utvrđivanjem i predviđanjem kvalitete života 133 osobe sestrinske profesije zaposlene u Kliničkom bolničkom centru Zagreb, na temelju njihovih sociodemografskih karakteristika, samoprocjene stresnosti posla i načina suočavanja sa stresom. Dobiveni rezultati djelomično su u skladu s očekivanjima. Kvaliteta života ispitanih medicinskih sestara pokazala se dobrom u svim domenama, ali stresnost posla je procijenjena jako visokom. Ispitane medicinske 
sestre najčešće koriste strategije suočavanja usmjerene na problem, a najrjeđe izbjegavajuće strategije. Viši stupanj obrazovanja i manja razina stresa na poslu ispitanih medicinskih sestara značajno predviđaju bolju kvalitetu života u domenama tjelesnog zdravlja i psihičkog stanja. Viša razina stresa ispitanih medicinskih sestara značajno predviđa lošiju kvalitetu života u domeni okoliša. Učestalije korištenje strategije izbjegavajućeg suočavanja sa stresom ispitanih medicinskih sestara značajno predviđa lošiju kvalitetu društvenih odnosa. Rezultati ovog istraživanja mogu biti korisni u osmišljavanju i planiranju promjena u organizaciji rada te edukaciji i intervencijama o suočavanju sa stresom za medicinske sestre zaposlene u bolnicama.

\section{LITERATURA}

Arafa, M. A., Nazel, M. W. A., Ibrahim, N. K. i Attia, A. (2003). Predictors of psychological well-being of nurses in Alexandria, Egypt. International Journal of Nursing Practice, 9, 313-320. DOI: 10.1046/j.1440-172X.2003.00437.x

Ashker, V. E., Penprase, B. i Salman, A. (2012). Work-related emotional stressors and coping strategies that affect well-being of nurses working in hemodialysis units. Nephrology Nursing Journal, 39(3), 231-236.

Aytekin, A., Kuguoglu, S. i Yilmaz, F. (2014). Burnout levels in neonatal intensive care nurses and its effects on their quality of life. Australian Journal of Advanced Nursing, 31(2), 39-47.

Belkic, K. i Nedic, O. (2007). Workplace stressors and lifestyle-related cancer risk factors among physicians: assessment using Occupational Stress Index. The Journal of Occupational Health, 49(1), 61-71.

Cai, Z., Li, K. i Zhang, X. (2008). Workplace stressors and coping strategies among Chinese psychiatric nurses. Perspectives in Psychiatric Care, 44(4), 223-231.

Carver, C. S. (1997). You want to measure coping but your protocol's too long: Consider the Brief COPE. International Journal of Behavioral Medicine, 4, 92-100. DOI: 10.1207/ s15327558ijbm0401_6

Carver, C. S., Scheier, M. F. i Weintraub, J. K. (1989). Assesing coping strategies: A theoretically based approach. Journal of Personality and Social Psychology, 56(2), 267-283.

Chen, C., Lin, C., Wang, S. i Hou, T. (2009). A study of job stress, stress coping strategies, and job satisfaction for nurses working in middle-level hospital operating rooms. Journal of Nursing Research, 17(3), 199-211. DOI: 10.1097/JNR.0b013e3181b2557b

Cimete, G., Gencalp, N. S. i Keskin, G. (2003). Quality of life and job satisfaction of nurses. Journal of Nursing Care Quality, 18(2), 151-158.

Dušak, M. (2012). Procjena emocionalne kompetencije i razine stresa kod medicinskih sestara u jedinici intenzivnog liječenja. Hrvatski časopis za javno zdravstvo, 8(31), 72-83.

Eriksen, W., Brauusgaard, D. i Knardahl, S. (2004). Work factors as predictors of intense or disabling low back pain; a prospective study of nurses' aides. Occupational and Environmental Medicine, 61, 398-404. 
Gazivoda, A. (2015). Stres na radnom mjestu medicinskih sestara i tehničara. Diplomski rad. Zagreb: Hrvatski studiji.

Golubić, R. (2010). Domene kvalitete života kao prediktori radne sposobnosti bolničkih zdravstvenih djelatnika (Doktorska disertacija). Zagreb: Medicinski fakultet Sveučilišta u Zagrebu. http://medlib.mef.hr/855/1/Golubic_R_disertacija_rep_855.pdf. Pribavljeno 16.03.2016.

Golubić, R. i Mustajbegović, J. (2011). Kvaliteta života zdravstvenih djelatnika. G. Vuletić (ur.), Kvaliteta života $i$ zdravlje (str. 9-16). Osijek: Filozofski fakultet Sveučilišta u Osijeku.

Hamaideh, S. H. (2012). Occupational stress, social support, and quality of life among Jordanian mental health nurses. Issues in Mental Health Nursing, 33, 15-23. DOI: $10.3109 / 01612840.2011 .605211$

Hudek-Knežević, J. i Kardum, I. (1993). Upitnik dispozicijskog i situacijskog suočavanja sa stresom i njegove psihometrijske značajke. Godišnjak Zavoda za psihologiju, 3, 43-62.

Hudek-Knežević, J., Kardum, I. i Vukomirović, Ž. (1999). The structure of copying styles: A comparative study of Croatian sample. European Journal of Personality, 13(2), 149161.

Hunter, B. (2004). Conflicting ideologies as a source of emotion work in midwifery. Midwifery, 20, 261-272. DOI: 10.1016/j.midw.2003.12.004

Jones, M. C., Wells, M., Gao, C., Cassidy, B. i Davie, J. (2013). Work stress and well-being in oncology settings: a multidisciplinary study of health care professionals. PsychoOncology, 22, 46-53. DOI: 10.1002/pon.2055

Knežević, B., Golubić, R., Milošević, M., Matec, L. i Mustajbegović, J. (2009). Zdravstveni djelatnici u bolnicama i stres na radu: istraživanje u Zagrebu. Sigurnost, 51(2), 85-92.

Krapić, N. i Kardum, I. (2003). Stilovi suočavanja sa stresom kod adolescenata: konstrukcija i validacija upitnika. Društvena istraživanja, 5(67), 825-846.

Lazarus, R. S. i Folkman, S. (2004). Stres, procjena i suočavanje. Jastrebarsko: Naklada Slap.

Lee, J. K. L. (2003). Job stress, coping and health perceptions of Hong Kong primary care nurses. International Journal of Nursing Practice, 9, 86-91. DOI: 10.1046/j.13227114.2003.00413.x

Lin, K., Huang, C. i Wu, C. (2007). Association between stress and work and primary headache among nursing staff in Taiwan. Headache, 47, 576-584. DOI: 10.1111/j.15264610.2007.00759.x

Loukzadeh, Z. i Mazloom, N. (2013). Association of coping style and psychological wellbeing in hospital nurses. Journal of Caring Sciences, 2(4), 313-319. doi: 10.5681/ jes.2013.037

Mačvanin, N. i Prokeš, B. (2005). Bolesti u vezi sa radom. Svet rada, 2(4), 531-539.

Marlais, M. i Hudorović, N. (2015). Stres uzrokovan radnim okruženjem medicinskih sestara/tehničara u Općoj bolnici Dubrovnik. Sestrinski glasnik, 20, 72-74.

Matulović, I., Rončević, T. i Sindik, J. (2012). Stres i suočavanje sa stresom-primjer zdravstvenog osoblja. Sestrinski glasnik, 17(3), 174-177.

Milošević, M., Golubić, R., Mustajbegović, J., Doko Jelinić, J., Janev Holcer i Kern, J. (2009). Regional pattern of physical inactivity in Croatia. Collegium antropologicum, $33(1), 35-38$. 
Milutović, D., Grujić, N. i Jokić, N. (2009). Identifikacija i analiza stresogenih faktora na radnom mestu medicinskih sestara - komparativna studija četiri klinička odeljenja. Medicinski pregled, 15(1-2), 68-73.

Onan, N., Isil, O. i Barlas, G. U. (2013). The effect of a new coping intervention on stress and burnout in Turkish oncology nurses. Journal of Marmara University Institute of Health Sciences, 3(3), 121-130. DOI: 10.5455/musbed.20130814120535

Pastuović, N., Kolesarić, V. i Krizmanić, M. (1995). Psychological variables as predictors of quality of life. Review of Psychology, 2(1-2), 49-61.

Pibernik-Okanovic, M. (2001). Psychometric properties of the World Health Organisation quality of life questionnaire (WHOQOL-100) in diabetic patients in Croatia. Diabetes Research and Clinical Practice, 51(2), 133-143.

Qiao, G., Li, S. i Hu, J. (2011). Stress, coping and psychological well-being among new graduate nurses in China. Home Health Care Management \& Practice, 23(6), 398-403.

Ribeiro, R. M., Pompeo, D. A., Pinto, M. H. i Ribeiro, R. H. M. (2014). Coping strategies of nurses in hospital emergency care services. Acta Paulista de Enermagem., 28(3), 216223. DOI: $10.1590 / 1982-0194201500037$

Skevington, S. M., Lotfy, M. i O'Connell, K. A. (2004). The World Health Organization's WHOQOL-BREF quality of life assessment: psychometric properties and results of the international field trial. A report from the WHOQOL group. Quality of Life Research, 13, 299-310. DOI: 10.1023/B:QURE.0000018486.91360.00

Sorić, M., Golubić, R., Milošević, M., Juras, K. i Mustajbegović, J. (2013). Shift work, quality of life and work ability among Croatian hospital nurses. Collegium Antropologicum, 37(2), 379-384.

Sveinsdottir, H., Biering, P. i Ramel, A. (2006). Occupational stress, job satisfaction, and working environment among Icelandic nurses: a cross-sectional questionnaire survey. International Journal of Nursing Studies, 43(7), 875-889. DOI: 10.1016/j.ijnurstu.2005.11.002

Vahey, D. C., Aiken, L. H., Sloane, D. M., Clarke, S. P. i Vargas, D. (2004). Nurse burnout and patient satisfaction. Medical Care, 42(2), 57-66. DOI: 10.1097/01. mlr.0000109126.50398.5a

Vuletić, G. i Misajon, R. (2011). Subjektivna kvaliteta života: povijesni pregled. G. Vuletić (ur.), Kvaliteta života $i$ zdravlje (str. 9-16). Osijek: Filozofski fakultet Sveučilišta u Osijeku.

Wakefield, B. J., Blegen, M. A., Uden-Holman, T., Vaughn, T., Chrischilles, E. i Wakefield, D. S. (2001). Organizational culture, continuous quality improvement and medication administration error reporting. American Journal of Medial Quality, 16(4), 128-134. DOI: $10.1177 / 106286060101600404$

Winwood, P. C., Winefield, A. H. i Lushington, K. (2006). Work related fatigue and recovery: the contribution of age, domestic responsibilities and shift work. Journal of Advanced Nursing, 56(4), 438-449. DOI: 10.1111/j.1365-2648.2006.04011.x

Wong, D. F. K., Leung, S. S. K. i So, L. K. O. (2001). Differential impacts of coping strategies on the mental health of Chinese nurses in hospitals in Hong Kong. International Journal of Nursing Practice, 7, 188-198. 
World Health Organization (1996). WHOQOL-BREF Introduction, administration, scoring and generic version of the assessment. Field Trial version. Programme on mental health. Geneva: WHO.

World Health Organization (1998). WHOQOL-BREF User manual. Programme on mental health. Geneva: WHO.

Wu, S., Li, H., Wang, X., Yang, S. i Qiu, H. (2011). A comparison of the effect of work stress on burnout and quality of life between female nurses and female doctors. Archives of Environmental \& Occupational Health, 66(4), 193-200. DOI: 10.1080/19338244.2010.539639

Yu, Y., Hu, J., Efrid, J.T. i McCoy, T.P. (2012). Social support, copying strategies and healthrelated quality of life among primary caregivers of stroke survivors in China. Journal of Clinical Nursing, 22, 2160-2171. DOI: 10.1111/jocn.12251

\title{
THE ASSOCIATION BETWEEN QUALITY OF LIFE AND COPING STRATEGIES IN NURSES
}

\begin{abstract}
The aims of this study were to examine quality of life, work-related stress and coping strategies among hospital nurses, and to identify the contribution of sociodemographic, work-related stress and coping strategies variables to the prediction of their quality of life in different domains. The study sample consisted of 133 nurses $(88 \%$ women) from 20 to 63 years old, employed at the Clinical Hospital Centre Zagreb. Instruments were: demographic characteristics and work-related stress questionnaire, Short version of COPE questionnaire, and World Health Organization Quality of Life - Brief Version questionnaire to test the quality of life in four domains: physical health, psychological health, social interaction and environment. Results showed good quality of life in all domains and high level of work-related stress. Participants most often used problem focused coping and rarely avoidance coping. A higher level of work-related stress and lower level of education were found to be significant predictors of poorer quality of life in physical and psychological health domains. Higher level of workrelated stress was a significant predictor of poorer quality of life in the environment domain. Frequent use of avoidance coping was a significant predictor of poorer quality of life in the social interaction domain. Results of this study can be useful for planning stress management interventions and education for nurses.
\end{abstract}

Key words: quality of life, nurses, work-related stress, coping strategies 